\title{
PRICE INTERACTIONS AND CAUSAL RELATIONSHIPS AMONG CORN, EXCHANGE RATE AND ANIMAL PROTEIN SOURCES IN NIGERIA
}

\author{
Unekwu Onuche ${ }^{\bowtie}$ \\ University of Africa, Nigeria
}

\begin{abstract}
Price transmissions between corn, exchange rate, poultry meat, and fish were investigated using the data from OECD-FAO for the years 1990-2019, to establish the existence of long-term relationships between them and identify their directions of causality, in order to elicit investmentaiding facts. The augmented Dickey-Fuller (ADF) test, the Johansen cointegration approach and the Granger causality test were employed. Following the ADF test, all series are $\mathrm{I}(1)$, while the cointegration test indicates short-run dynamics between them. The Vector Autoregressive (VAR) system reveals that poultry meat price influences all variables, prices of poultry meat and exchange rate relate positively to their own lags, and exchange rate relates positively to lags of poultry meat prices. A positive relationship was noticed between fish price and lags of poultry meat price, while corn price relates positively with lags of poultry meat price. Granger causality tests indicate unidirectional drives from poultry price to fish price, the exchange rate to fish price and poultry meat price to corn price. Responses from prices of fish, corn and poultry to innovations from exchange rate are negative, while positive responses exist in other scenarios. Exchange rate stabilization will mitigate external risks, especially to the fisheries sector, while corn farmers can increase profits in the short-run by exploring knowledge of poultry meat price movements.
\end{abstract}

Keywords: prices, corn, exchange rate, animal protein, cointegration, causality

\section{INTRODUCTION}

Although its contribution to total GDP fell from its level of $65 \%$ in the 1960 s (Oluwafemi et al., 2015), to the level of 21.91\% in2019 (Plecher, 2020), owing to a plethora of constraints (Ojeka et al., 2016), agriculture has continued resiliently as a major sector of the Nigerian economy. For years following independence, it was the largest contributor to GDP and the leading earner of foreign exchange. It is however now the third-largest contributor to GDP, but still provides about $80 \%$ of food demand, contributes significantly to foreign exchange earnings, provides raw materials for industry and engages tens of millions of Nigerians, who, according to FAO (n.d) constitute two-thirds of the labor force. These capacities of agriculture have been leveraged upon by governments to reduce unemployment, achieve food sufficiency and reduce poverty.

Poverty reduction requires that agricultural participants receive increased income sufficient to sustainably stay above the poverty line (Vos, 2015). To achieve this, market expansion is necessary for increased production. Market opportunities required for increased production and income for agricultural producers reside in the increasing food and raw material needs, which is occasioned by the rising population.

Markets for fish and poultry subsectors are expanding. Beside the population increase, conscious dietary

\footnotetext{
$\bowtie$ Unekwu Onuche, Department of Agricultural Economics and Extension, University of Africa, Toru Orua, Bayelsa, Nigeria, e-mail: unekwu.onuche@uat.edu.ng, https://orcid.org/0000-0001-7551-8144
} 
habits are also driving the consumption of these commodities (Birch, 2019). Relatedly, the capacities to satisfy these markets are enormous. Nigeria's potential for fish production is in her water reserves for aquaculture development, a largely untapped continental shelf(Onuche et al., 2020; Evbuomwan et al., 2005; Ssetongo et al., 1986) as well as a large youth population. Enlightenment drives on homestead production have also increased fish and poultry meat production.

The derived demand for corn in the production of these protein sources, in addition to its increasing use for biofuel production, has the capacity to further push up the county's corn demand of, thereby creating larger markets for it. Hence, great opportunities abound for the producers of these commodities. Exploring such potentials, however, requires the understanding of market situations of product prices and input costs.

Costs of feeds comprise between 60 and $70 \%$ of animal production (Swain, 2016) and determine profit levels. World over, pressure from the use of corn in animal feed and biofuel is driving up its prices (Musunuru, 2015; Zhang and Reed, 2008). Nigeria, the largest corn producer in Africa, contributes $0.9 \%$ to the world total (Olaniyan, 2015). The country's corn output grows at $6.7 \%$ on average per annum but can be increased to take advantage of the expanding market. Up to $70-80 \%$ of corn produced in the world is used for animal feed production (Qi et al., 2004). Corn constitutes $40-70 \%$ of poultry feed and $25 \%$ of fish feed but could be much higher. While higher prices are forcing producers to cut the amount of corn in fish feed, a minimum of $15 \%$ is canvassed to "ensure proper expansion and floatability of feed pellets" (Menghe and Robinson, 2013).

The pressure on this commodity increases the uncertainty and risks related to its price and consequently, the profits obtainable from the production of its derivatives, such as animal protein sources. Such risks, as enumerated in studies by Musunuru (2015) and Mueller and Mueller (2016), are out of the control of primary producers and permeate the entire production chain (Amarante et al., 2018). Part of this chain is linked to the derived demand for primary products which translates to input costs in other production activities. For instance, the price of Corn influences the prices of feeds, which in turn determines the costs of poultry and fish. A relationship in the opposite direction is also possible (Musunuru, 2015), but not in all cases (Taru, 2014).
Another factor likely to influence the prices of commodities is the exchange rate. A weak currency can spur exports, leading to market expansion and higher returns. Reversely, a strong currency can contract exports and lead to higher input prices (Musunuru, 201) especially in cases where inputs are externally sourced. Studies have shown how volatile the Nigerian economy is to the vagaries of the exchange rate (Manasseh et al., 2016; Fasanya and Olawepo, 2018). Information on input cost and exchange rates is, therefore, a vital element in production planning. Hence, agricultural businesses will benefit from reliable information about market and production environments.

The knowledge of key phenomena like price movements, interrelationships and causality is of importance to Nigerian agriculture, especially as it is transitioning from the subsistence level to a more business-oriented activity. Such pieces of information are crucial to profit, utility maximization and economic sustainability (Amarante et al., 2018). Economic volatility, including dwindling GDP and inflation also bring to fore the need to improve awareness as regards the cost of production and returns. Producers plan to take advantage of higher prices for their products, while also undertaking some form of economic adaptation, including the choice of cheaper alternatives, to reduce cost.

Price movement analyses seek to guide producers in their production planning to ensure business sustainability, overcome imperfection and maximize profits. These analyses are basically undertaken using time series autoregressive techniques such as cointegration. Cointegration is an econometric property (Gujarati, 2004), implied by a stationary linear combination of two or more series which themselves are non-stationary (Yusuf and Olukosi, 2015). The cointegration technique has been used to investigate the integration of prices for a number of commodities across different areas. In Nigeria, this technique has been applied in the non-agricultural sector (Asaolu and Ilo, 2012; Gil-Alana and Yaya, 2014; Nkechukwu and Onyeaga, 2015) and the agricultural sector (Akinbode and Adekunle, 2017; Yusuf and Olukosi, 2015; Taru, 2014, Nkang et al., 2006), with mixed results. Akinbode and Adekunle (2017) find that rural market prices influenced urban market prices of yellow maize in western Nigeria. Yusuf and Olukosi (2015) did not find any cointegrating relationship between prices of "Pomo" (animal skin processed for food) for Kano and Lagos states. Furthermore, Taru 
(2014) finds mixed results for a number of commodities in northeastern Nigeria. Finally, Nkang et al. (2006) find contrasting reactions of cocoa export to its real price in the short and long runs. These works do not attempt to investigate price transmission between the prices of agricultural commodities and those of their derivatives that is analyzed by Amarante et al. (2018), Rudinskaya (2019), Musunuru (2015), Nazlioglu and Soytas (2012) for other places. Hence this work was undertaken to explain price transmissions and causal relationships between corn, exchange rate, poultry meat and fish in Nigeria. The study focused on corn, a major component of animal feed, and its derived products of poultry meat and fish.

These variables were selected for the study because of their strategic importance in the Nigerian agricultural economy and nutrition. As earlier noted, corn is an important raw material in some sectors and has been subject to much pressure. On the other hand, poultry meat and fish constitute important sources of animal protein for Nigerians. Compared to other animal protein sources such as ruminants, they are easier to produce and are beneficial in dieting. The productions of these animal protein sources are linked to corn. About $55.6 \%$ of poultry production in Nigeria is undertaken under semi-intensive and intensive systems (Africa..., 2018), implying reliance on manufactured feeds. On the other hand, about $28 \%$ of Nigerian fish supply is produced under the aquaculture system (Onuche et al., 2020), also implying the use of manufactured feed. In both cases, corn constitutes a significant component of the manufactured feeds. The inclusion of exchange rate as a variable is due to the fact that corn, fish and poultry products, as well as some of their production inputs are still being imported into the country, hence, their prices are exchange rate sensitive.

In order to explain price transmissions and causations among these variables, the existence of cointegration and causality in the transmission of prices between corn, exchange rate and prices of fish and poultry meat are investigated to establish whether or not long term relationships exist among the variables, and identify the direction of causality among them. The goal is to use evidence obtained as a guide for investment and risk mitigation strategies. The other sections of the paper include estimation data and techniques, results and discussion, and finally, the conclusion.

\section{MATERIALS AND METHODS}

\section{Data and data sources}

Data were obtained from the OECD-FAO agricultural outlook for Nigeria. They include average annual prices of fish in Naira/ton (F), corn in Naira/ton (C), poultry meat in Naira/ton (P) and the Exchange rate -Naira per USD (E), over the period spanning 1990-2019. It is to be noted that the annual average Dollar to Naira exchange rate as at 2019 was 0.0028 . In addition to the descriptive statistics, data were analyzed in the natural log forms designated as $\mathrm{LnF}$ (fish prices), $\mathrm{LnC}$ (corn prices), $\mathrm{LnP}$ (poultry price) and $\mathrm{LnE}$ (exchange rate). The variables were logged in accordance with the standard practice in time series econometric analysis, especially to reduce skewness as noticed in this study, reduce outliers and their effects, as well as aid in the interpretation of results.

\section{Unit root test for stationarity}

Stationarity implies that the stochastic properties of a time series do not vary with time (Gujarati, 2004). The test for cointegration is preceded by the stationarity test in order to avoid spurious results (Gujarati, 2004). Two methods are available for use in this test- Dickey-Fuller (DF) and Augmented Dickey-Fuller (ADF), established by Dickey and Fuller $(1979,1981)$. In the Dickey-Fuller test, the null hypothesis of $\gamma=1$ is tested. In the event that $\gamma=1$, there exists a unit root and the series is said to be non-stationary, otherwise, the series is stationary. The $\mathrm{DF}$ equation is given as:

$$
\Delta \mathrm{P}_{\mathrm{t}}=\beta+\gamma \mathrm{P}_{\mathrm{t}-1}+\alpha \mathrm{t}+\partial_{1} \Delta \mathrm{P}_{\mathrm{t}-1}
$$

An extension of DF, the ADF (which tests the same null hypothesis) is however mostly used because of its inclusion of a higher-order regressive process. It is given by:

$$
\Delta \mathrm{P}_{\mathrm{t}}=\beta+\gamma \mathrm{P}_{\mathrm{t}-1}+\alpha \mathrm{t}+\partial_{1} \Delta \mathrm{P}_{\mathrm{t}-1}+\partial_{2} \Delta \mathrm{P}_{\mathrm{t}-2}+\ldots+\partial_{\mathrm{z}} \Delta \mathrm{P}_{\mathrm{t}-\mathrm{z}}+\mathrm{e}_{\mathrm{t}}(2)
$$

Where $\Delta$ is the difference operator, $\mathrm{t}$ is time, $\beta, \gamma, \alpha$, $\partial_{1}, \partial_{2}$ and $\partial_{z}$ are parameters to be estimated.

Following Nkang et al. (2006), this study employed the ADF approach to testing the stationarity of the variables employed in the study.

\section{Cointegration}

Cointegration is a tool for investigating the presence of long-run relationships between multivariate time series. Engel and Granger (1987), as noted in Nazlioglu and 
Soytas (2012) and Johansen (1988), provide approaches to investigating this phenomenon. The Engle-Granger procedure is a two-step method that works first by creating system residuals before testing them for the presence of a unit root. Its shortcoming is that it can indicate more than two cointegrating equations in the case of more than two variables. Again, it is a single-variable equation. Johansen's procedure deals with some of these flaws by permitting more than one cointegrating equation and being suitable for multiple variables.

Following Musunuru (2015), and upon establishing that the series are integrated of order 1, the cointegration was tested in this work using Johansen cointegration test. In this test, the null hypothesis is stated as $\mathrm{H}_{\mathrm{o}}: r$ $=0$. That is, there is no cointegrating vector between any combination of the variables. The alternative is stated as $\mathrm{H}_{1}: r \neq 0$ implying that there exists a cointegrating vector in at least one combination of the variables. In the event that the alternative hypothesis is upheld, we may conclude, at the established error level, that the series are cointegrated, and long-run equilibrium relationship(s) exist(s) between them. In interpreting the above test, we consider the Johansen trace statistic and the maximum Eigen statistic. In the event that their calculated values are higher than their critical values at the pre-determined permissible level of error ( $5 \%$ in this study), the $\mathrm{H}_{0}$ is rejected and a conclusion is made to the effect that at least a cointegrating equation exists, otherwise a cointegrating relationship fails to hold. In the event that at least a cointegrating equation exists, the Vector Error Correction Model (VECM) is applied to explain the dynamics of series movement in the short- and long run. Should there exist no cointegrating equation, an unrestricted Vector Autoregressive (VAR) system is modeled.

\section{Granger Causality}

The Granger causality test is used to evaluate the predictive capacity of a single variable on other variables in the system (Musunuru, 2015). If lagged values of a variable (S) can be better used to predict another variable (Q) even when the lagged forms of $Q$ are taken into consideration, then S is said to Granger-cause Q. Such a test reveals the direction of causation. This direction, if it exists, can be unidirectional or bidirectional. Thus, this methodology consists of bidirectional/unidirectional characteristics. Following Alexander (2001), we consider a VAR ( $\mathrm{p}$ ) model for $\mathrm{Q}$ as follows:

$$
\mathrm{Q}_{\mathrm{t}}=\partial_{1}+\Sigma_{k=1}^{\rho} \beta_{1 \mathrm{k}} \mathrm{Q}_{\mathrm{t}-\mathrm{k}}+\ldots \Sigma_{k=1}^{\rho} \varphi_{1 \mathrm{k}} \mathrm{S}_{\mathrm{t}-\mathrm{k}}+\mathrm{e}_{1 \mathrm{t}}
$$

The test of Granger causality from $\mathrm{Q}$ to $\mathrm{P}$ is an $\mathrm{F}$ test on $\beta_{2 \mathrm{ki.e.}} \beta_{21} \ldots \beta_{2 \mathrm{p} \text {. }}$

Similarly, VAR (p) model for $\mathrm{S}$ is specified as:

$$
\mathrm{S}_{\mathrm{t}}=\partial_{2}+\Sigma_{k=1}^{\rho} \beta_{2 \mathrm{k}} \mathrm{Q}_{\mathrm{t}-\mathrm{k}}+\ldots \Sigma_{k=1}^{\rho} \varphi_{2 \mathrm{~K}} \mathrm{~S}_{\mathrm{t}-\mathrm{k}}+\mathrm{e}_{2 \mathrm{t}}
$$

In which the joint significance of $\varphi_{11 \ldots} \varphi_{1 \mathrm{p}}$ are also tested based on the $\mathrm{F}$ ratio.

\section{RESULT AND DISCUSSION}

\section{Descriptive statistics of study variables}

The descriptive statistics of the study variables in Table 1 indicate a wide dispersion in fish price. Fish price ranged from 2,100.47 Naira (USD 262.56) per ton in 1990 to $468,771.40$ Naira (USD 1,298.14) per ton in 2019 , with a mean of 115261.10 Naira (USD 910.75) per ton. Wide dispersions were also noted for the other variables. The standard deviation, a measure of the dispersion of the series around their means was highest for poultry meat prices and lowest for exchange rates. Generally, all variables appear to be highly volatile. However, the coefficient of variation $(\mathrm{CoV})$ was highest for fish price at $108.6 \%$, making it the most volatile of the series. The risk level and volatility of the price of corn comes next $(\mathrm{CoV}=85.9 \%)$ and is closely followed by that of poultry meat $(\mathrm{CoV}=85.1 \%)$, while the most stable of the variables was the exchange rate $(\mathrm{CoV}=78.6 \%)$. A few known factors are responsible for the instability of prices in Nigeria. First, the Nigerian economy is highly dependent on oil, which is why changes in crude oil prices affect the prices of local commodities. Abdulkareem and Abdulkareem (2016) report that the price of crude is a major source of macroeconomic volatility in Nigeria. This variable, since it is internationally determined, also affects the stability of the prices of export commodities which, according to Manasseh et al (2016) are also responsible for price volatility in Nigeria. For prices of agricultural products, in particular, information shocks from Consumer Price Index, exchange rates and oil markets are key drivers of volatility (Fasanya and Olawepo 2018). Estimates also indicate that all variables are skewed while non-Zero kurtosis is also indicated for all of them. 
Onuche, U. (2021). Price interactions and causal relationships among corn, exchange rate and animal protein sources in Nigeria. J. Agribus. Rural Dev., 1(59), 59-67. http://dx.doi.org/10.17306/J.JARD.2021.01387

Table 1. Descriptive statistics of study variables

\begin{tabular}{lrrrr}
\hline \multicolumn{1}{c}{ Statistic } & $\begin{array}{c}\text { Price of fish } \\
(\mathrm{F})\end{array}$ & $\begin{array}{c}\text { Price of corn } \\
(\mathrm{C})\end{array}$ & \multicolumn{2}{c}{ Price of } \\
poultry meat $(\mathrm{P})$ & \multicolumn{2}{c}{ Exchange rate } \\
Mean & $115,261.1$ & $20,219.60$ & $189,510.6$ & 126.56 \\
Median & $73,968.08$ & $14,442.30$ & $145,013.8$ & 127.24 \\
Maximum & $468,771.4$ & $53,220.15$ & $551,926.3$ & 361.68 \\
Minimum & $2,100.47$ & 842.94 & $8,692.680$ & 8.04 \\
Std. deviation & $125,142.50$ & $17,378.41$ & $161,263.3$ & 99.53 \\
CoV. & 1.08 & 0.86 & 0.85 & 0.79 \\
Skewness & 1.45 & 0.53 & 0.72 & 0.93 \\
Kurtosis & 4.27 & 1.91 & 2.51 & 3.46 \\
Jarque-Bera & 12.49 & 2.91 & 2.89 & 4.56 \\
\hline
\end{tabular}

Source: own computation for secondary data.

\section{Augmented Dickey-Fuller (ADF) tests results of study variables}

Table 2 presents the results of the unit roots test conducted using ADF on the variables. ADF Results at level indicate non-rejection of the Ho at 5\%, implying non-stationary characteristics, hence the presence of unit roots in all 4 series. The series were however I(1), implying that VECM or VAR can be used to model the relationships between any combination of the variables. The ultimate decision on this is dependent on the results of the cointegration test.

Table 2. ADF tests results of study variables

\begin{tabular}{cccc}
\hline Variables & At level & At first difference & Conclusion \\
\hline LnF & -2.06 & -5.64 & $\mathrm{I}(1)$ \\
$\mathrm{LnC}$ & -1.98 & -4.39 & $\mathrm{I}(1)$ \\
$\mathrm{LnP}$ & -1.80 & -6.73 & $\mathrm{I}(1)$ \\
$\mathrm{LnE}$ & -1.77 & -4.93 & $\mathrm{I}(1)$ \\
\hline
\end{tabular}

At level, $1 \%=3.697,5 \%=2.968,10 \%=2.622$, at first difference, $1 \%=3.689,5 \%=2.97210 \%=2.651$

Source: own computation for secondary data.

\section{Results for Johansen cointegration test for study variables}

Following the establishment of the optimum lag length(1) using the AIC, the Johansen cointegration test was conducted to confirm the presence or otherwise of long-term equilibrium relationships between any combinations of the variables. Table 3 indicates that statistical evidence is not enough to support the cointegration hypothesis, implying that only short run dynamics exist between the prices of corn, fish and poultry meat as well as the exchange rate. Accordingly, the VAR system is the appropriate modeling technique as against the VECM. Hence, using the optimal lag length of 1 as in the cointegration test, the VAR system was modeled.

Table 3. Results for Johansen cointegration test for study variables

\begin{tabular}{lcccc}
\hline $\begin{array}{c}\mathrm{H}_{\mathrm{o}}: \text { Rank }=r \\
\text { (number of } \\
\text { cointegrating } \\
\text { equation) }\end{array}$ & Eigenvalue & $\begin{array}{c}\text { Trace } \\
\text { statistics }\end{array}$ & $\begin{array}{c}5 \% \text { critical } \\
\text { value }\end{array}$ & $\begin{array}{c}\text { Proba- } \\
\text { bility }\end{array}$ \\
\hline None & 0.540875 & 44.18057 & 47.85613 & 0.1062 \\
At most 1 & 0.390422 & 22.38444 & 29.79707 & 0.2776 \\
At most 2 & 0.201099 & 8.524743 & 15.49471 & 0.4111 \\
At most 3 & 0.076826 & 2.238249 & 3.841466 & 0.1346 \\
\hline
\end{tabular}

Source: own computation for secondary data 
Onuche, U. (2021). Price interactions and causal relationships among corn, exchange rate and animal protein sources in Nigeria. J. Agribus. Rural Dev., 1(59), 59-67. http://dx.doi.org/10.17306/J.JARD.2021.01387

Table 4. VAR results on interrelationships among research variables

\begin{tabular}{lllll}
\hline \multicolumn{1}{c}{ Variables } & \multicolumn{1}{c}{ LnF } & \multicolumn{1}{c}{ LnC } & \multicolumn{1}{c}{ LnP } & \multicolumn{1}{c}{ LnE } \\
\hline LnF(-1) & 0.272671 & -0.204611 & -0.157842 & -0.149138 \\
& {$[1.08892]$} & {$[-1.09788]$} & {$[-0.87033]$} & {$[-0.89202]$} \\
LnC(-1) & -0.259241 & 0.283782 & -0.037156 & -0.357507 \\
& {$[-0.75555]$} & {$[1.11126]$} & {$[-0.14952]$} & {$[-1.56054]$} \\
LnP(-1) & 0.843925 & 0.681961 & 1.219340 & 0.418289 \\
& {$[2.79521]^{*}$} & {$[3.03485]^{*}$} & {$[5.57618]^{*}$} & {$[2.07498]^{* *}$} \\
LnE(-1) & 0.168050 & 0.258163 & -0.076781 & 1.053702 \\
& {$[0.75786]$} & {$[1.56426]$} & {$[-0.47808]$} & {$[7.11691]^{*}$} \\
Adj. R-squared & 0.904911 & 0.939446 & 0.934950 & 0.931527 \\
Sum sq. resids & 4.043413 & 2.239813 & 2.121021 & 1.802582 \\
S.E. equation & 0.402165 & 0.299320 & 0.291275 & 0.268521 \\
F-statistic & 89.82072 & 145.7985 & 135.1469 & 127.9727 \\
\hline
\end{tabular}

$*$ and **implies significance at $5 \%$ and $10 \%$ respectively. Lm test: $14.789(0.5401)$

Source: own computation for secondary data.

\section{VAR results on interrelationships between research variables}

Results from the VAR model presented in Table 4 show that price of poultry meat and exchange rate are positively related to their lagged values. Other variables do not demonstrate any significant relationships with their lagged values even at $10 \%$ level. The exchange rate are positively related to the lag of poultry meat prices. Fish price, on the other hand, demonstrated a positive relationship with the lag of the prices of poultry meat. In addition, corn prices are positively related to the lag of poultry meat prices. The Granger causality test helps to further explain these relationships by indicating the directions of influence.

\section{Pairwise Granger causality tests between study variables}

Next, the causality test was carried out to explain which of the price variables can be better used to predict the others, using their lagged values. Table 5 indicates the rejection of the null hypotheses in a few cases. It indicates that the price of poultry meat Granger-causes the price of fish at 5\%. It is plausible to infer that increases in the price of poultry meat can push the demand for fish up, thereby leading to some increase in the price of fish. Furthermore, the hypothesis that the exchange rate does not Grange-cause fish price is rejected at $10 \%$.
Table 5. Result of pairwise Granger causality tests between study variables

\begin{tabular}{ccc}
\hline $\mathrm{H}_{\mathrm{o}}$ & $F$ statistics & $p$-value \\
\hline $\mathrm{LnC} \nRightarrow \mathrm{LnF}$ & 2.48275 & 0.1272 \\
$\mathrm{LnF} \nRightarrow \mathrm{LnC}$ & 0.21867 & 0.6440 \\
$\mathrm{LnP} \nRightarrow \mathrm{LnF}$ & 6.80638 & $0.0149^{*}$ \\
$\mathrm{LnF} \nRightarrow \mathrm{LnP}$ & 0.82291 & 0.3727 \\
$\mathrm{LnE} \nRightarrow \mathrm{LnF}$ & 3.04084 & $0.0930^{*}$ \\
$\mathrm{LnF} \nRightarrow \mathrm{LnE}$ & 0.30413 & 0.5860 \\
$\mathrm{LP} \nRightarrow \mathrm{LnC}$ & 5.90607 & $0.0223^{*}$ \\
$\mathrm{LnC} \nRightarrow \mathrm{LnP}$ & 0.06187 & 0.8055 \\
$\mathrm{LnE} \nRightarrow \mathrm{LnC}$ & 2.40824 & 0.1328 \\
$\mathrm{LnM} \nRightarrow \mathrm{LnE}$ & 0.51770 & 0.4782 \\
$\mathrm{LnE} \nRightarrow \mathrm{LnP}$ & 0.01638 & 0.8991 \\
$\mathrm{LnP} \nRightarrow \mathrm{LnE}$ & 0.21158 & 0.6494 \\
\hline
\end{tabular}

$\nRightarrow$ mean "does not Granger cause", * and **implies significance at 5 and $10 \%$ respectively

Source: own computation for secondary data

Hence, the price of fish is driven by the exchange rate in a unidirectional relationship. The vulnerability of the 
price of fish to the exchange rate may not be unrelated to the fact that fish is one of the most imported food commodities in Nigeria, and requires enormous amounts of foreign exchange. For instance, in 2016, fish import cost was estimated at 125 billion nairas (Onuche et al., 2020). The dollar equivalent of this sum in 2019 was $350,000,000$ USD.

Finally, the $\mathrm{F}$ ratio is also robust enough to conclude that poultry meat prices drive the price of corn. The results do not indicate any bidirectional drive. Signals from poultry prices can be received by farmers who are aware that corn constitutes about $40-70 \%$ of components in poultry feed and that it has no viable absolute alternatives. This means that, largely, the poultry farmer, depending on other variables, is a price taker. Thus, the demand for corn by the poultry farmer tends towards being price inelastic in this case. But this may not easily reflect on the prices of poultry meat as its demand is elastic, owing to the availability of close substitutes such as fish. Poultry World (2020) reports that while the price of corn more than doubled between March and August 2020, the prices of poultry only witnessed an insignificant increase. Elsewhere, Musunuru (2015) reports bi-directional causation between corn and lean hogs.

\section{Orthogonal impulse responses}

Results of impulse response functions in Fig. 1 indicate that apart from the responses of the prices of fish, corn and poultry to innovations from exchange rate which are

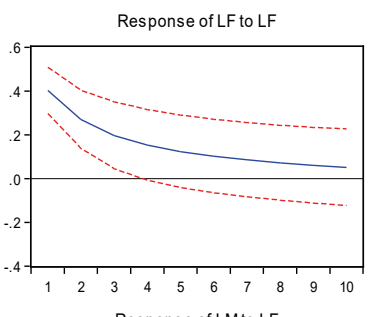

Response of LM to LF

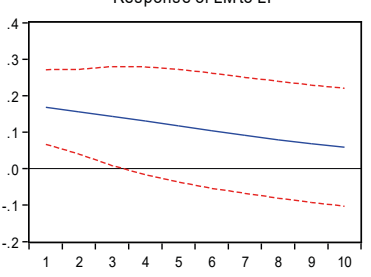

Response of LP to LF

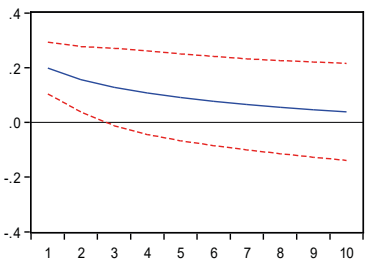

Response of LE to LF

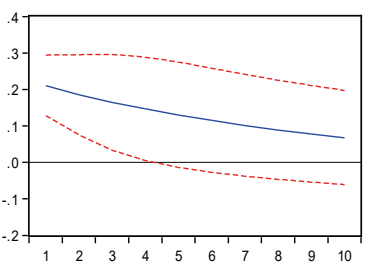

Response to Cholesky One S.D. Innovations \pm 2 S.E.

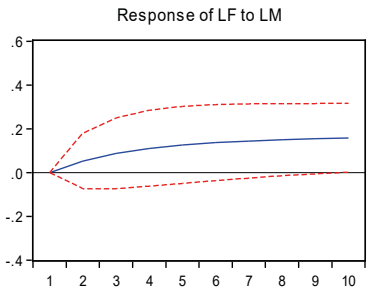

Response of LM to LM

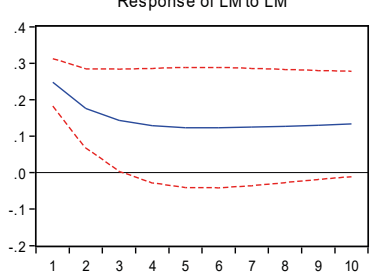

Response of LP to LM

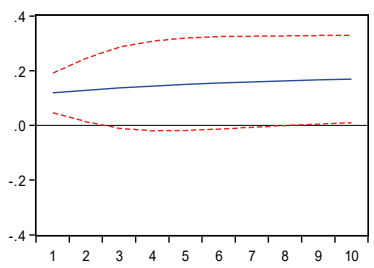

Response of LE to LM

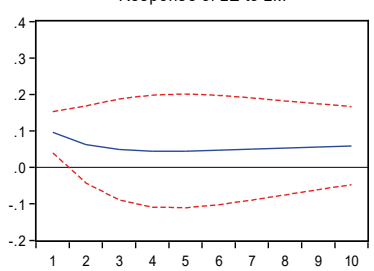

Response of $L F$ to $L P$

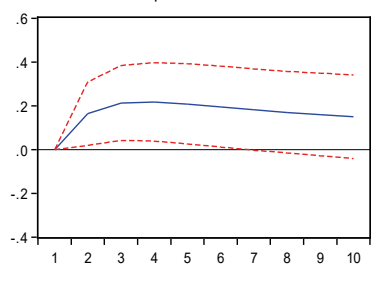

Response of LM to LP

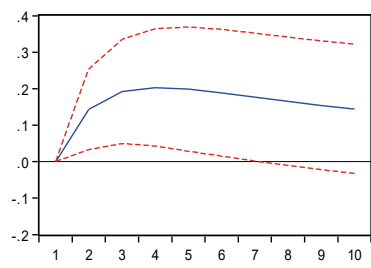

Response of $L P$ to $L P$

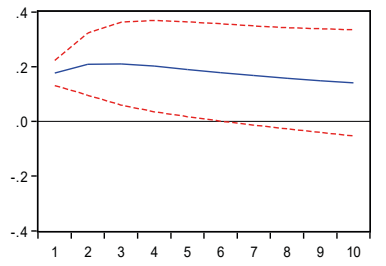

Response of LE to LP

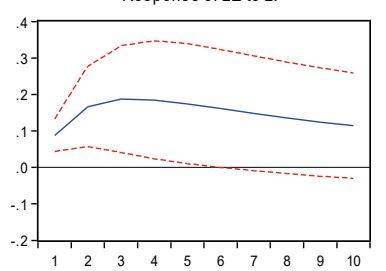

Response of LF to LE

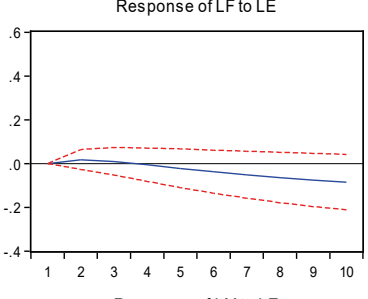

Response of LM to LE

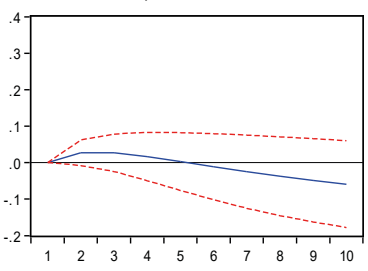

Response of $L P$ to $L E$

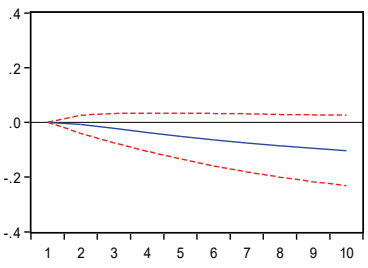

Response of LE to LE

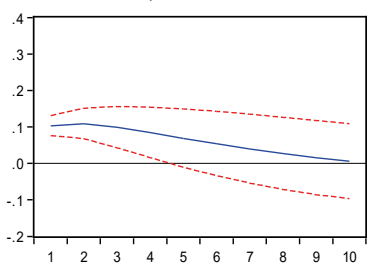

Fig. 1. Results on orthogonal impulse function Source: own computation for secondary data. 
negative (that of poultry was initially positive), responses to shocks in other scenarios are positive.

Responses of poultry price to shock from fish price as well as those from exchange rate to its own innovations were steadily declining.

\section{CONCLUSION}

This paper sought to explain price transmission and causation between corn, exchange rate, poultry meat, and fish. This was aimed at providing agricultural stakeholders with information that would aid planning and hedging operations in order to optimize production and profit. The result of the cointegration test reveals that only short run relationships could be modeled between the variables. It was found that the exchange rate drives fish prices probably due to the imports of fish and fish production inputs. Not surprisingly, innovations to the exchange rate elicit negative responses from other variables. It is important, therefore, for sound exchange rate management policies to be put in place in order to minimize its volatility and possible negative effect on production and profits. Poultry meat prices are noticed to be drivers of corn prices, with the latter demonstrating a positive response to innovation in the former. This information might be useful to corn farmers in planning towards increased production and profit. The fact that fish prices are driven by the prices of poultry meat can be useful for hedging operations and plans by the producers of both commodities.

\section{REFERENCES}

Abdulkareem, A., Abdulkareem, K.A. (2016). Analysing oil price-macroeconomic volatility in Nigeria. Central bank of Nigeria Journal of Applied statistics, 7,1a, 1-22.

Africa Sustainable Livestock 2050 (2018). Livestock and livelihoods spotlight Nigeria (cattle and poultry sectors). Rome: FAO.

Akinbode, S.O., Adekunle, C.P. (2017). Price transmission and market integration of yellow maize in south western Nigeria. Cointegration and vector error correction model approach. Eur. J. Econ. Manag. Sci., 17(2), 14-23; http:// dx.doi.org/10.20534/EJEMS 17-2-14-23

Alexander, C. (2001). Market Models: A Guide to Financial Data Analysis. New York: Wiley.

Amarante, J.G.M.C., Bach, T.M.,Vieira da Silva, W., Matiollo, D., Souza, A., Pereira da Veiga, C. (2018). Econometric analysis of cointegration and causality between markets prices toward futures contracts: Evidence from the live cattle market in Brazil. Cogent Bus. Manag., 5, 1457861; https://doi.org/10.1080/23311975.2018.1457861

Asaolu, T.O., Ilo, B.M. (2012). The Nigerian stock exchange and oil price: a cointegration analysis. Kuwait Chapt. Arab. J. Bus. Manag. Rev., 1(6), 109-118.

Birch, J. (2019). Wellness: from fish to bacon, a ranking of animal protein in order of healthfulness. Wash. Post., July, 3.

Dickey, D.A., Fuller, W.A. (1979). Distribution of the estimators for autoregressive time series with a unit root. J. Am. Stat. Assoc., 74(366), 427-431. https://doi.org/10.1080/01 621459.1979 .10482531

Dickey, D.A., Fuller, W.A. (1981). Likelihood ratio statistics for autoregressive time series with a unit root. Econometrica, 49(4), 1057-1072; https://doi.org/10.2307/1912517

Engel, R.F., Granger, C.W.J. (1987). Cointegration and error correction: Representation, estimation, \& testing. Econometrica, 55(2), 251-276.

Evbuomwan, G.O., Momah, A.P., Sere-Ejembi, A.A., Sodipo, J.A., Bada, A. (2005). Self-sufficiency in the fishery subsector: challenges and prospects in Lagos state. Lagos: Central Bank of Nigeria.

FAO (n.d). Nigeria at a glance. Retrieved August $25^{\text {th }} 2020$ from:http:/www.fao.org/nigeria/fao-in-nigeria/nigeria-ata-glance/en/

Fasanya, I., Olawepo, F. (2018). Determinants of food price volatility in Nigeria. Agric. Tropic. Subtropic., 51(4), 165-174.

Gil-Alana, L.A., Yaya, O.S. (2014). The relationship between oil prices and Nigerian stock market. An analysis based on fraction integration and cointegration. J. Energy Econ., 64, 328-333; https://doi.org/10.1016/j.eneco.2014.10.001

Gujarati, D.N. (2004). Basic Econometrics (4 $\left.4^{\text {th }} \mathrm{ed}\right)$. India: McGraw-Hill.

Johansen, S. (1988). Statistical analysis of cointegration vectors. J. Econ. Dyn. Cont., 12(2-3), 231-254; https://doi. org/10.1016/0165-1889(88)90041-3

Li, M.H., Robinson, E.H. (2013). Feed Ingredients and Feeds for Channel Catfish. Southern Regional Aquaculture center. Publication No 1806. 6PP

Manasseh, C.O., Ogbuabor, J.E., Obinna, O.K. (2016). Volatility and commodity price dynamics in Nigeria. Int. J. Econ. Fin. Iss., 6(4), 1599-1607.

Menghe, H. L., Robinson, E.H. (2013). Feed Ingredients and Feeds for Channel Catfish. SRAC Publication No. 1806. Retrieved 27th July 2020 from: http://fisheries.tamu.edu/ files/2013/09/SRAC-Publication-No.-1806-Feed-Ingredients-and-Feeds-for-Channel-Catfish.pdf

Mueller, B., Mueller, C. (2016). The political economy of the Brazilian model of agricultural development: Institutions 
versus sectoral policy. Quart. Rev. Econ. Fin., 62, 12-20; https://doi.org/10.1016/j.qref.2016.07.012

Musunuru, N. (2015). Causal relationships between grain, meat prices and exchange rates. Int. J. Food Agric. Econ., 5(42017), 1-10.

Nazlioglu, S., Soytas, U. (2012). Oil price, agricultural commodity prices, and the dollar: A panel cointegration and causality analysis. J. Energy Econ., 34(12), 1089-1104; https://doi.org/10.1016/j.eneco.2011.09.008

Nkang, N.M., Abang, S.O., Akpan, E.O., Offem, K.J. (2006). Cointegration and error correction modelling of agricultural export in Nigeria: The case of cocoa. J. Agric. Soc. Sci., 2(4), 249-255.

Nkechukwu, G., Onyeaga, J. (2015). Macroeconomic variables and stock prices in Nigeria: cointegration and vector error correction model tests. Int. J. Soc. Sci. Res., 6(4), 717-724.

Ojeka, G.O., Effiong, C.E., Eko, E.O. (2016). Constraints to agricultural development in Nigeria. Int. J. Dev. Econ. Sust., 4(2), 1-15.

Olaniyan, B.A. (2015). Maize: panacea for hunger in Nigeria. Afr. J. Plant Sci., 9(3), 155-174. Retrieved 24th February 2020 from: https://academicjournals.org/article/article1427453934 OLANIYAN.pdf

Oluwafemi, Z.O., Adedokun, M.A., Ogunleye, A.A., Oladokun, Y.O.M. (2015). An Empirical Analysis of the Contribution of Agricultural Sector to Nigerian Gross Domestic Product: Implications for Economic Development. Dev. Countr. Stud., 5(21), 36-42.

Onuche, U., Oladipo, M.A., Enize, T., Daikwo, D. (2020). Perception and uptake of Aquaculture technologies in Kogi state, central Nigeria: imperative for Improved Management practices for sustainable aquaculture development. Afr. J. Agric. Res., 16(6), 819-828; https://doi. org/10.5897/AJAR2019.14558

Plecher, H. (July 28, 2020). Nigeria: Distribution of gross domestic product (GDP) across economic sectors from 2009 to 2019. Retrieved Aug $20^{\text {th }}$ from https://www.statista. com/statistics/382311/nigeria-gdp-distribution-acrosseconomic-sectors

Poultry World (2020). Nigeria: Shortage of maize is crippling the poultry industry. (Aug $19^{\text {th }}$ ). Retrieved Dec $12^{\text {th }}$
2020 from: https://www.poultryworld.net/Meat/Articles/2020/8/Nigeria-Shortage-of-maize-is-crippling-thepoultry-industry-628784E/

Qi, G., Diao, Q., Tu, Y., Wu, S., Zhang, S. (2004). Nutritional evaluation and utilization of QUALITY protein maize in animal feed in FAO: Protein sources for the animal feed industry. Proceedings of expert consultation and workshop, Bangkok (185-198).

Rudinskaya, T. (2019). Asymmetric price transmission analysis in the Czech pork market. J. Cent. Eur. Agric., 20(3), 986-994; https://doi.org/10.5513/JCEA01/20.3.2278

Ssetongo, E.W., Ukpe, G.T., Ajayi, T.O. (1986). Marine fishery resources of Nigeria: a review of exploited fish stocks. CECAF/ECAF series 86/40 (En); http://www.fao.org/3/ r9004e/R9004E01.htm

Swain, B.K. (2016). Low cost feed formulation for rural poultry production: In: A.K. Panda, A. Kumar, B. Sahoo, S. Tanuja (Eds.), Empowering farmwomen through livestock and poultry intervention (pp. 186-194). ICAR Central Institute for Women in Agriculture.

Taru, B. (2014). Price fluctuation and market integration of selected cereal in north-eastern Nigeria, 2001-2010. PhD thesis in the department of Agricultural Economics, University of Nigeria, Nsukka.

Vos, R. (2015). Agricultural transformations, growth and poverty. UNU-WIDER 30th Anniversary Conference Helsinki, 18 September 2015. Retrieved February 13th 2020 from: https://www.wider.unu.edu/sites/default/files/ Events/PDF/Slides/Vos.pdf

Yusuf, O., Olukosi, J.O. (2015). Cointegration and market integration: an application to hides and pomo markets in in Nigeria. Am. J. Exp. Agric., 7(1), 62-69.

Zhang, Q., Reed, M. (2008). Examining the impact of the world crude oil price on China's agricultural commodity prices: The case of Corn, Soybean, \& Pork. Paper Presented at the Southern Agricultural Economics Association Annual Meetings, Dallas, TX. Retrieved May 24th 2020 from: http://citeseerx.ist.psu.edu/viewdoc/summary?doi= 10.1.1.549.6653 
